\title{
Behind her Cosmopolitan Beauty: Transnational Modern Girl in Japan and Republican China
}

\author{
Duanduan Zhou \\ Department of Comparative Literature, Hong Kong University, Central and Western District, Hong \\ Kong, China \\ zoeychou1998@gmail.com
} Keywords: Modern girl, Modernity, Consumerism, Advertising, Visual Culture, Feminine beauty,
Republican China, Meiji Japan

\begin{abstract}
Under the overwhelming tide of Western-dominated modernization, the modern girl image appeared around the globe during the 1920s and 1930s through the means of advertising, embellishing and transforming the visual sphere of modern experience. As a consumerist icon highly constructed by media and a product of capitalist commodification of the female body, the modern girl embodies the spontaneity and autonomy of consumer culture at the same time. This paper analyzes the visual archives of the modern girl from Japan and Republican China, exploring the image-making of modern girl in the national, cultural and gender dimension.
\end{abstract}

\section{Introduction}

The modern girl (moga), a quintessential cultural icon of consumerism, emerged in the urban streets of Japan in the late 1920s and transformed the visuality of Japanese public sphere since then. In the scholarly and media discourse, she is generally depicted as an independent, hedonistic, and arguably decadent middle-class consumer who pursues westernized fashions and lifestyles ${ }^{1}$. During the interwar period, these moga made an impressive appearance in Japanese cosmetics and fashion advertising, reflecting the transforming ideals for feminine beauty and hygiene with the efflorescence of modernity. Drawing on the visual archives of Shiseido cosmetics advertising, this essay looks into the rise of Japanese modern girl who is a carefully crafted consumerist icon lingering between her Japanese-ness, transnationality, and modernity. Likewise, the Chinese equivalent of Japanese moga, modeng xiaojie, ascended the cosmopolitan stage of Shanghai early in the Republican era (19111949), acting out fantasy scenes of Shanghai's prosperity and modernity. Through the juxtaposition of Japanese and Chinese modern girl images, this essay further explores the nuances between Japanese and Chinese experience of modernity in a nationalistic discourse.

\section{Japanese modern girl}

\subsection{Modern girl as a media construct}

The Modern Girl first came into the public discourse of Japan in a 1924 article published in the woman's magazine Josei. The author, Kitazawa Shūich, presented the modern girl as an apolitical while liberated, self-respecting and autonomous female figure who kept abreast with their male peers ${ }^{2}$. The social critic Nii Itaru, credited for coining the term modan gaaru, further distinguished the modern girl with little political aspirations from the "social girl" who advocated for women's rights and equality. He portrayed the modern girl as aggressive and erotic whereas took an ambiguous tone in expounding her social and political attributes ${ }^{3}$. As such, the fascinating modern girl remained a vague subject yet to be defined in the media discourse of the 1920s and 1930s. First and foremost,

\footnotetext{
${ }^{1}$ Miriam Silverberg, "The modern girl as militant," in Recreating Japanese Women: 1600-1945, ed. Gail Lee Bernstein, (Berkeley: University of California, 1991), pp. 239-66.

${ }^{2}$ Ibid., 240 .

${ }^{3}$ Ibid., 241.
} 
body aesthetics came into play in the character sketch of a Japanese modern girl. She stood out in the urban streets with her short hair and long, straight legs, which arguably implies her growing independence and ability to create a new life ${ }^{4}$. Abandoning traditional oriental aesthetics, the modern girl would not shy away from flaunting her sightly figure such as protruding buttocks. More prominently, she was usually characterized by a fascination with westernized and fashion-forward clothing in the media discourse - although a 1925 survey of women in Ginza district indicated only $1 \%$ dressed in Western-style clothing. In this sense, the modern girl is largely defined by the superficiality such as her body, fashion, and the implied sexuality, which makes her a figure closely associated with media and consumption. Just as Silverberg contends, she was "a highly commodified cultural construct" crafted by the media who debated her identity during the era of drastic societal changes ${ }^{5}$.

\subsection{A fabricated consumerist icon}

The modern girl debate provides an intriguing window into the gendered dimensions of modernity rooted in the profound economic, social, and cultural transformation taking place in the 1910s and 1920s. The first World War brought to Japan a spectacular economic boom, followed by a prolonged postwar recession intensified by the 1923 Kantō Earthquake and the global financial crisis ensued. Although the catastrophe in 1923 devastated the capital Tokyo and its surrounding areas, the postearthquake "reconstruction boom" fostered a budding cosmopolitan urban culture centering on the department stores, modern cinema, cafes, print media and leading-edge innovations in business ${ }^{6}$. In particular, the newly emerging publishing industry enjoyed an exuberance despite economic uncertainty. Diverse publications including magazines, books, and newspapers celebrated the modern lives of middle-class women and men, boosting a common experience of Japanese modernity ${ }^{7}$. This phenomenon, arguably, reflects the domestic anxieties to catch up with the western powers and modernize their civilian life.

Beyond the rise of print media, the emergent capitalism economy spawned new products and growing possibilities of consumption, leading to the outlook for a new urban life ${ }^{8}$. The dazzling array of consumer goods such as clothing and cosmetics in the department stores celebrated a capitalist consumer culture, one that permeated the life of Japanese middle-class women. Modern girls, the most high-profile female consumer, were represented as strolling on the Ginza streets, shopping at the department stores and hanging out at the cafes, setting a consumerist and aesthetic trend for Japanese women. She as thus ascended to the most sought-after female icon featured in the commercial ads in the dawning era of modern commercial design. With large budgets, the multinational and domestic cosmetic companies widely promoted their products through advertising in the new media, portraying the modern girl with carefully made-up faces, bobbed hair and fashionable clothing ${ }^{9}$. The prevalence of Modern Girl style in cosmetics ads reflects the new ideals of contemporary beauty and hygiene, shaping the cultural landscape of modern Japan.

\subsection{Modernizing aesthetics: Shiseido cosmetics advertising}

\subsubsection{Brand image and target customers}

The Japanese cosmetics company Shiseidō, founded in 1872 as the first Western-style pharmacy, was and continues to be a leading national cosmetics manufacturer in Japan. Selling and advertising beauty products geared primarily towards female consumers, Shiseidō played an influential role in shaping the visuality of feminine beauty and health, and thus shaped Japanese modern experience in

\footnotetext{
${ }^{4}$ Ibid., 242.

${ }^{5}$ Ibid., 240.

${ }^{6}$ Gennifer Weisenfeld. “Selling Shiseido I," MIT Visualizing Cultures, $<$ https://visualizingcultures.mit.edu/shiseido_01/index.html $>$ [accessed 4 May, 2019].

${ }^{7}$ Gordon, Andrew. "Japan in Wartime", in A Modern History of Japan: From Tokugawa Times to the Present. 3rd edition. (New York: Oxford University Press, 2013), 202-222.

${ }^{8}$ Ibid., 220.

${ }^{9}$ Alys Eve Weinbaum et al. (eds.), "The Modern Girl Around the World”, in The Modern Girl around the World: Consumption, Modernity, and Globalization. (Durham, N.C.: Duke University Press, 2008). 8-12.
} 
the interwar era. The Shiseidō company has introduced a diversity of beauty products over the decades, most prominently including the toothpaste, face powers, vanishing and cold creams, perfumes, and soap $^{10}$. Beyond a staggering array of high-quality merchandise, innovative product development and manufacturing, Shiseidō company also pioneered in its package and advertising design under the influence of the vibrant commercial design culture abroad.

Shiseido's brand image was built by a dazzling array of elegant women with various racial identities from across the ages. The historical female figures from Japanese imperial heyday, wearing their dramatic porcelain-white make-up and gorgeous robes, came to the focus in Shiseidō's ads of the early Taishō era, evoking nostalgia for Japanese traditional aesthetics among the populace ${ }^{11}$. Meanwhile, the Western classical beauties from Roman and Italy made brief while impressive appearances in the cosmetics advertising, evoking images of a western cosmopolitan lifestyle and a concept of transnational, universal beauty. Before long, the classical female images gave way to the newly emerged icons of contemporary beauty, such as a modish-style Japanese woman wearing a 20th-century upswept coiffure (sokuhatsu) and stylish kimono ${ }^{12}$.

Shiseido geared its beauty products towards various types of female consumers in the contemporary era, ranging from the new woman (atarashii onna), the working woman (shokugyō fujin), the housewife (shūfu), to the modern girl (moga) ${ }^{13}$. Accordingly, Shiseido cosmetics ads portrayed modern independent women with different social roles, advocating a universal pursuit of skin perfection.

\subsubsection{Brand image and target customers}

As a trend-setter of contemporary beauty and a self-reliant middle-class consumer, the modern girl was an undisputed focus of Shiseido's sophisticated advertising campaigns. The 1927 Cold Cream poster below (fig. 1) features an impressively beautiful woman who enjoys a fantasy life of luxury and leisure. At first sight, her short wavy hair, western-style gown, and exquisite jewelry presumably reveal her identity as an epicurean modern girl. Attended by a dark-skinned servant, the woman gracefully singles out the cold cream from a dazzling array of beauty products. The mirror reflecting her sightly image seemingly invites the gaze of an external audience, both the sexualized male gaze and the inquisitive gaze from other women. As Weisenfeld interprets it, the woman's flashy lifestyle is presumably supported by a wealthy husband who is fascinated with her timeless beauty maintained by diligent skin care; the attentive servant reminiscent of colonial subjects further implies her western origin $^{14}$. In this light, this female subject is more likely a western bourgeois housewife than a Japanese modern girl. The Caucasian women featured in early Shiseido posters conveyed a western idea of universal and cosmopolitan beauty, one that inspired modern girls in Japan to westernize their appearance and lifestyles.

\footnotetext{
${ }^{10}$ Gennifer Weisenfeld. "Selling Shiseido I," MIT Visualizing Cultures, $<$ https://visualizingcultures.mit.edu/shiseido_01/index.html $>$ [accessed 4 May, 2019].

${ }^{11}$ Ibid.

${ }^{12}$ Ibid.

${ }^{13}$ Ibid.

${ }^{14}$ Ibid.
} 


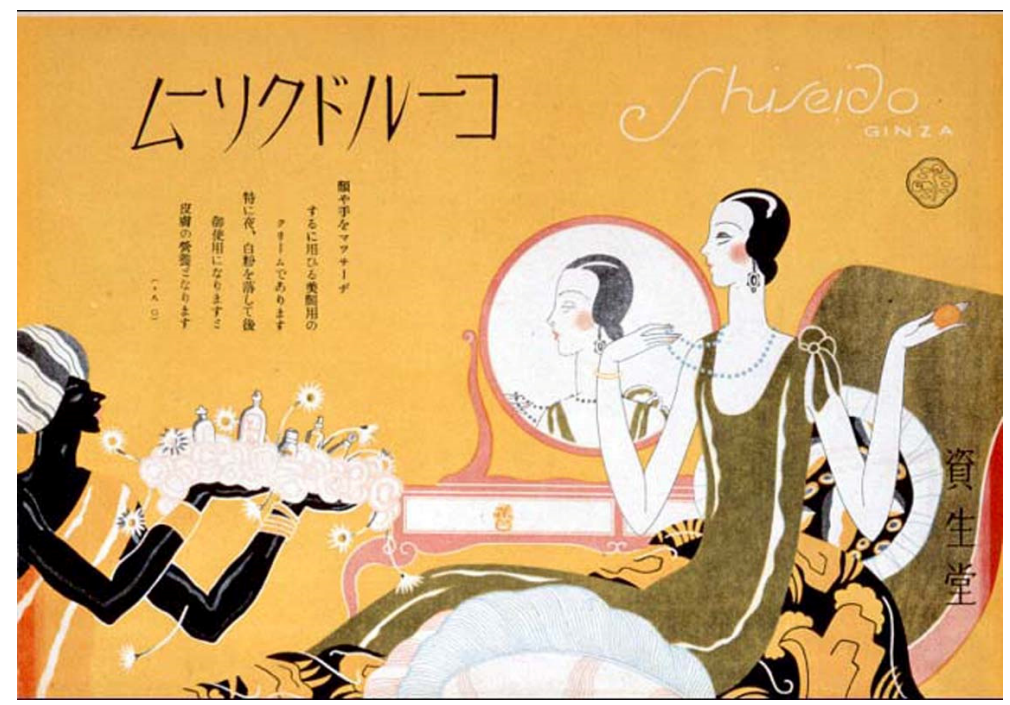

Fig.1 Shiseido cold cream poster, 1927.

\subsubsection{Marketing campaigns}

Beyond the print promotion, Shiseido company further initiated a dazzling array of marketing campaigns which included the establishment of the Shiseido Parlour retail store in Ginza, the expansion of a chain store network, and the launch of public relations publications ${ }^{15}$. In its absorbing magazine Shiseido Graph (formerly titled Shiseido Monthly, established in 1924), the recurring modern girl imagery was recreated in a highly mannerist style during the 1930s, which embodied an aesthetic development from the naturalist art nouveau to a more abstract graphic style ${ }^{16}$. At the same time, Shiseido increasingly adopted photography and photomontage in its editorial design, which aroused a strong cinematic association. A 1933 issue of Shiseido Graph featured a dramatic close-up of an alluring Japanese modern girl with her stylish hat, bobbed hair, impressive make-up and a cool face (fig. 2) ${ }^{17}$. The erogenous and mysterious feminine beauty of this modern girl reinforced the aesthetic association with movie stars. In this way, Shiseido advertising initiated a visual communication with the flourishing modern cinema, which is an imported product from the west and an emblem of modernization and industrialization.

After the full eruption of Asia-Pacific war in 1937, Japan's militarist leaders directed a campaign against the "luxury" and westernized aesthetics promoted by cosmetic companies, which markedly transformed Shiseido's early westernized female models into Asian subjects ${ }^{18}$. In a 1940 Shiseido promotional poster, a conspicuously Asian beauty with a western-style suit is portrayed as feeling and scrutinizing her skin (fig. 3). The advertising slogan praises Shiseido beauty products as the "peak of purely domestic products", promoting a sense of national pride that echoed with the on-going expansionist war. More than a product of social gendering, the modern girl imagery ultimately fits into a complex matrix of gender, race, social class and modernity. Shiseido's interwar advertising represented the modern girl as a highly transnational imagery, one that constantly lingering between her Japanese-ness and westernized modernity. By juxtaposing Japanese Modern Girl with her European equivalents, Shiseido strived to place Japanese contemporary women equally in a modern discourse with western women. Back in the domestic context, she was nonetheless subject to a suspicious social gaze contributed by the patriarchal conservatives, feminist New Women and other social undercurrents. 


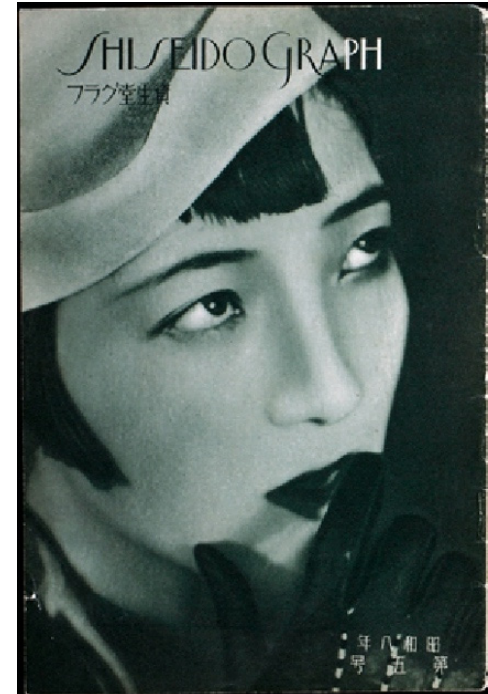

Fig. 2 Shiseido Graph 5, cover, November 1933.

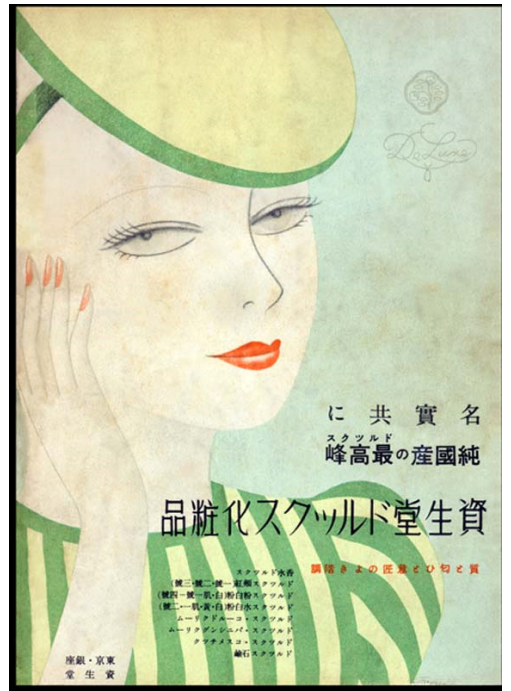

Fig. 3 Shiseido cosmetics ad, 1940.

\subsubsection{Hybrid style and imperial modernity}

Beyond visualizing a stunning array of transnational modern girls, Shiseido also invited glamorous movie stars to promote their beauty products, most prominently the advertising icons from Manchukuo. The Chinese-born Japanese actress and singer Yamaguchi Yoshiko (Li Xianglan), notoriously represented as an ambassadress of the "friendship" between imperial Japan and its colony Manchukuo, featured in a 1941 Shiseido soap advertisement geared towards Manchurian (fig. 4). Framed by a soft pink feather fan metonymically evoking China or Manchuria, Yamaguchi glances provocatively at the audience in the guise of a Chinese modern girl ${ }^{19}$. This advertisement was carefully crafted with common tropes that Japanese viewers would have associated with glamourous images of actresses depicted in Shanghai-published women's pictorials - the feather fan, seductive gaze and short permed hair ${ }^{20}$. The garb of Yamaguchi remains hidden behind the feather fan in this image, while another Shiseido face cream advertisement (fig. 5) more conspicuously depicts her in a traditional Chinese cheongsam, with jade earrings, consistent permed haircut and immaculate makeup. Intriguingly, most ads of Shiseido and other cosmetic companies that geared their products towards Manchukuo showed a model in a cheongsam in order to maintain her specifically Chinese identity $^{21}$. Her highly crafted Chinese-style appearance served as a camouflage for the imperial modernity promoted by these Japanese cosmetics companies.
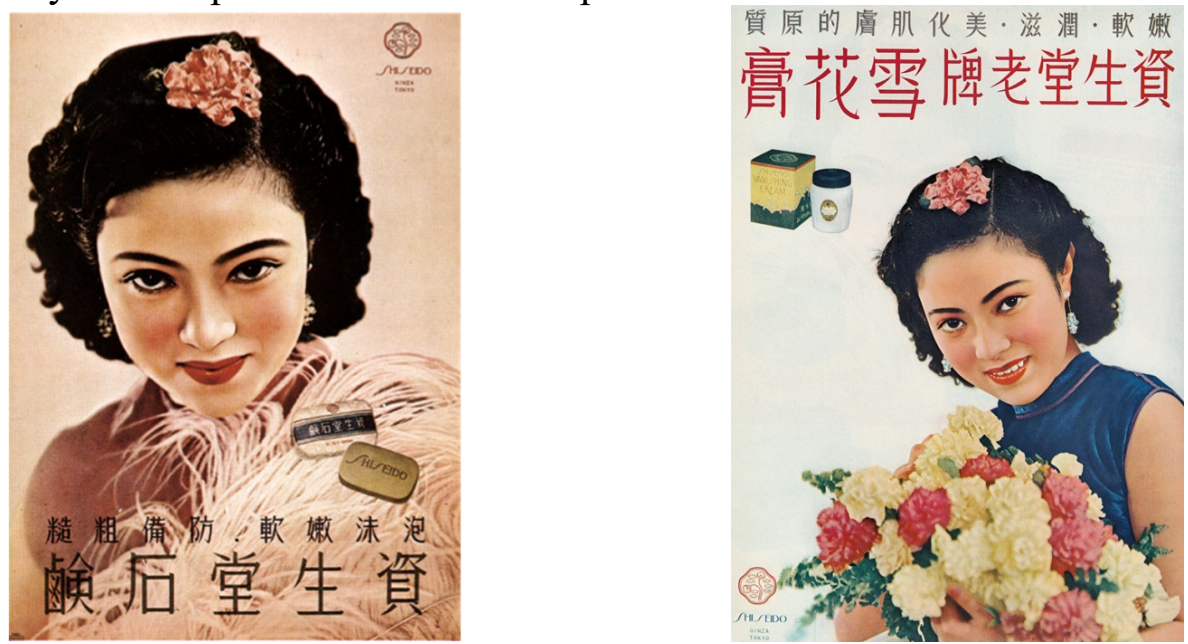

Fig. 4 \& Fig. 51941 image of Yamaguchi Yoshiko for Shiseidô soap \& face cream.

\footnotetext{
${ }^{19}$ Annika A. Culver, "Shiseidō's 'Empire of Beauty': Marketing Japanese Modernity in Northeast Asia, 1932-1945," Shashi: The Journal of Japanese Business and Company History 2.1 (2013): 6-22.

${ }^{20}$ Ibid., 19.

${ }^{21}$ Ibid., 20.
} 


\section{Chinese modern girl}

\subsection{Hybrid style and cosmopolitan beauty}

\subsubsection{The burgeoning urban culture}

Penetrated by the prevailing Western culture, Republican China (1911-1949) during the interwar period experienced an efflorescence of urban culture resembling Japanese modern experience. In the 1920s, Chinese modern girl modeng xiaojie ascended to the stage of the cosmopolitan city and treaty port, Shanghai, acting out the imaginary social scenes connoting Shanghai's economic exuberance and fantasy ${ }^{22}$. The Chinese modern girl emerged with another culture figure known as the New Woman who represented female strength and the nation's prospect for modernity. By contrast, the image of the modern girl connotated women's decadence, cultural loss and unforeseen danger embedded in Chinese modern experience, which echoes scholars' criticism upon Japanese moga. The young, vibrant female images and photographs, balanced between occidental and cosmopolitan aesthetics, began inviting a public gaze in the emerging female-oriented magazines, which subverted the puritanical taboo under Qing dynasty that women should not be seen in public. Moreover, reckoned as a quintessential icon of the emerging consumerist culture, the image of the Chinese modern girl was also carefully crafted and highly commodified through advertising.

The magazine Young Companion (Liang You), founded in 1926 as the first comprehensive pictorial, pioneered in featuring modern girls with their fashion sketches, advertising images and photographs, constructing a public realm for upper-class Chinese women to display their image. The 1927 cover (fig. 6) of Young Companion features a female socialite icon of the time know as Lu Xiaoman, who wears a western-style furry overcoat, holds a Chinese folding fan, smiles demurely and glances provocatively at the viewers, in a manner intriguingly resembling Yamaguchi in Shiseido's Manchurian advertisement. Despite a relatively conservative haircut, her eye-catching make-up, western garb and earrings undeniably set an aesthetic trend for modern girls of her time. The cover girls featured in Young Companion and other women's pictorials were exclusively female celebrities with an independent and prominent social status, such as movie stars and social butterflies, thus reconstructing the modern identity of Chinese women through their unconventional beauty and lifestyles.

As a quintessential embodiment of Republican-era female fashion, Chinese dress cheongsam became a common sight in the media's representation of modern girls. The juxtaposition of two Young Companion cover girl images (fig. 7) reveals the subtle transformation of cheongsam over time: The legendary Shanghainese movie star Ruan Lingyu is photographed wearing a conservative aqua checked cheongsam in the 1934 cover image, while the 1941 cover portrays another modern girl dressed in sleeveless cheongsam with a gaudier design, indicating an on-going liberation of female aesthetic conception.

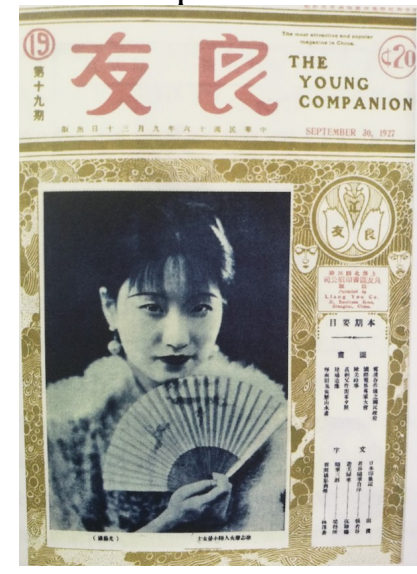

Fig. 61927 Cover of Young Companion.

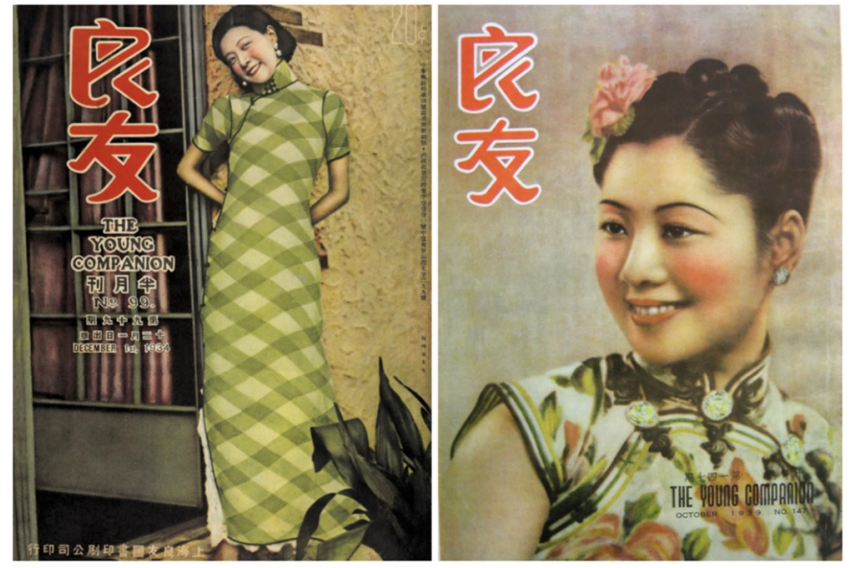

Fig. 7 Cover of Young Companion, 1934 and 1941.

\footnotetext{
${ }^{22}$ Sarah E. Stevens. "Figuring Modernity: The New Woman and the Modern Girl in Republican China," NWSA Journal 15. 3(2003), 82-103.
} 


\subsubsection{Cultural and national hybridity in the image-making}

Besides an iconoclastic public display of female beauty, the new Republication era also lifted the restriction on female consumption in public sphere and thus liberated the purchasing power of women, which became a motivating source for the evolving consumerist economy ${ }^{23}$. The Nanjing decade (1927-1937), credited as a golden era for the national economy, most prominently witnessed a flourish of domestic and foreign commodities such as cosmetics, fabrics, cigarettes and other fancy "modern" commodities ${ }^{24}$. Against the backdrop of a thriving consumption culture, the commercial newspapers and female-oriented magazines were inundated with advertisements promoted in a Modern Girl style. In particular, the American skincare brand Pond successfully marketed its beauty products in China by playing tactfully with images of Chinese women. Figure 8 juxtaposes the newspaper ads of Pond's face cream from three different periods, depicting a cosmopolitan modern girl, a traditional housewife and a young bride who unanimously favor Pond's face cream out of their universal pursuit of perfect skin. Conspicuously drawing on a western style, the modern girl to the left looks staggeringly ahead of her time in her avant-garde coat and high-heels. By contrast, the traditional Han-Chinese garb in the middle represents a less modern dressing style adopted by most Chinese civilians. Advertising with Chinese female figures from various social classes, Pond implanted a new ideal of affordable and universal beauty into its target consumers, meanwhile tactfully avoiding potential nationalist sentiments associated with western products.
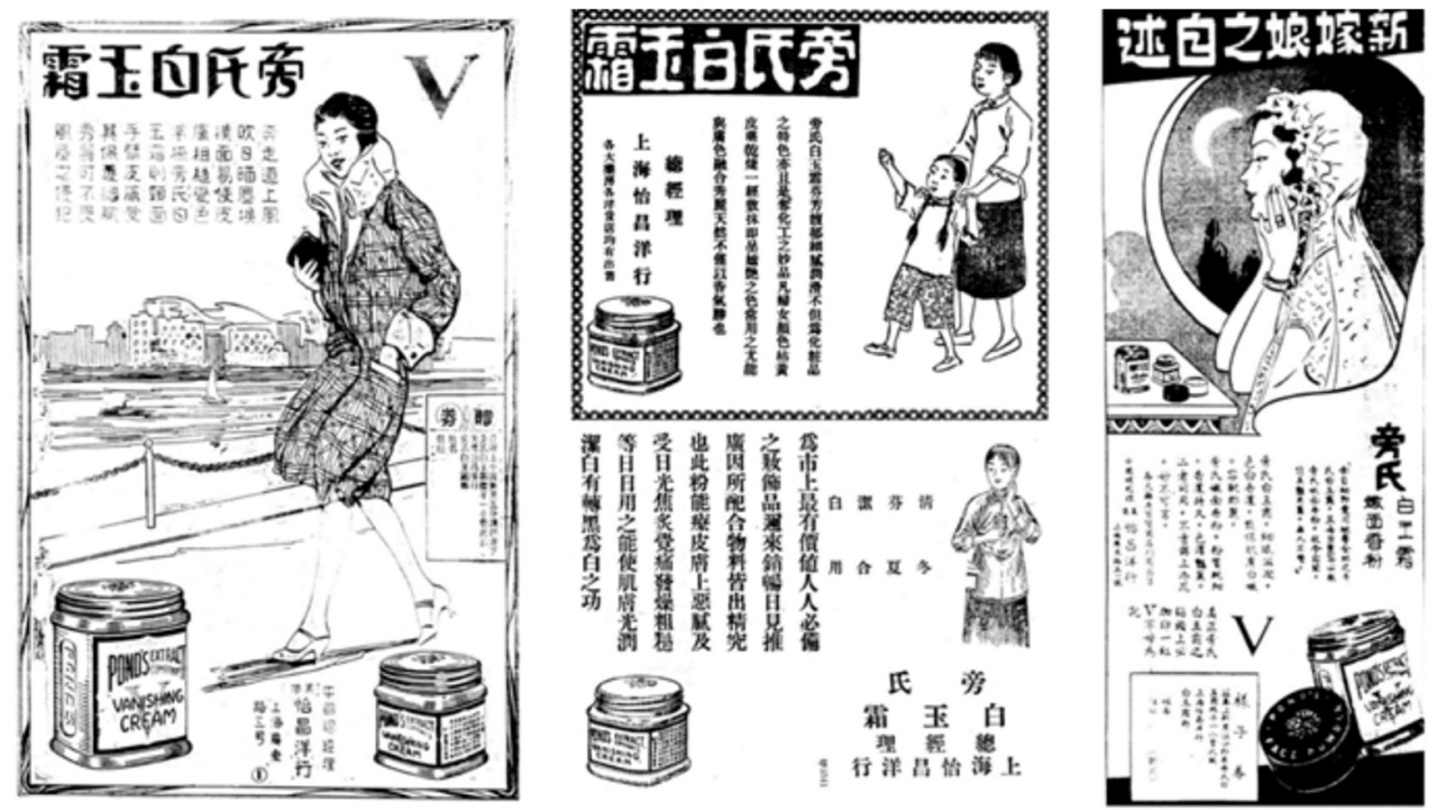

Fig. 8 Pond's face cream ads in News Press, 1929, 1920, 1935 from left to right.

Playing with a similar strategy, Coca Cola further invited the glamourous Shanghainese movie star Ruan Lingyu to endorse its products (fig. 9), making a great coup in opening the Shanghai market. It is noticeable that Ruan wears a modified gauzy cheongsam that highlights her graceful figure better than the traditional ones. On balance, it was a prevailing advertising practice for foreign corporations to endow their commodities with a sort of Chinese-ness by incorporating uniquely indigenous elements. This strategy highly echoes with Shiseido's "imperial advertising" in Manchuria during Japanese occupation, revealing a symbiotic relationship between Chinese modern experience and external aggression.

\footnotetext{
${ }^{23}$ Laikwan Pang. "Advertising and the Visual Display of Women," in The distorting mirror: visual modernity in China. (Honolulu: University of Hawaii Press, 2007), 102-130.

${ }^{24}$ Madeleine Y. Dong. "Who is afraid of the Chinese modern girl?" in The Modern Girl around the World: Consumption, Modernity, and Globalization. (Durham, N.C.: Duke University Press, 2008), 194-219.
} 


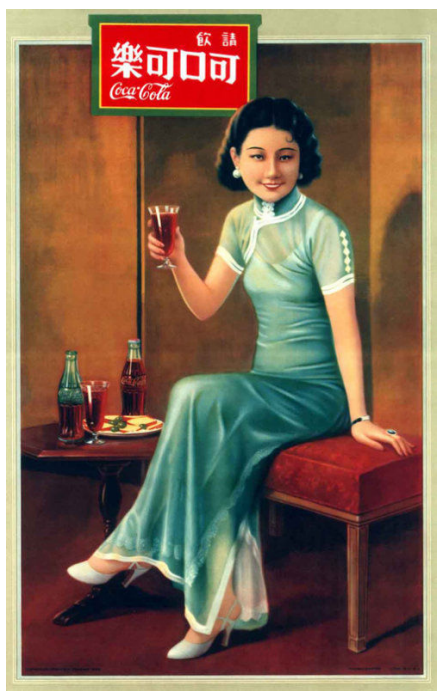

Fig. 9 Shanghainese movie star Ruan Lingyu in 1927 Coca Cola poster.

Compared to Japanese commercial ads of the time, Chinese advertising design was unique in exploring another form of visual possibility, the calendar poster (yuefenpai) which emerged in late Qing and was widely popularized during the Republican era. The most common design of calendar posters featured a centrally positioned female model surrounded by commodities and an imported Gregorian calendar ${ }^{25}$. For instance, the 1934 calendar poster (fig. 10) for the Australian Lactogen milk powder depicts a female model in an attractive and sprightly manner, despite her weak association with the commodity itself. With no comparable fame and charisma as Ruan Lingyu, most calendar girls were basically empty signifiers whose significations depend more on the dominant discourse of consumerism than on the commodity ${ }^{26}$. These exquisitely dressed calendar grils symbolized the "aestheticization of everyday life", an ideal that the visual system of calendar poster strived to construct and propagate ${ }^{27}$. Absorbingly, the juxtaposition of the Coca Cola ad with the milk powder poster reveals a transforming aesthetic standard of cheongsam: the side slit tended to be higher up to the hip over time, exposing more of the female body. Another calendar poster of Yuanhe Trading Company (fig. 11) sheds more light on this trend: the female model sits in a seductive posture that reveals her underskirt, with the high-heels pointing suggestively to the products. Her modified cheongsam is a hybrid fashion combining western and Chinese style, one that is less conservative and secretive about female sex appeal and more provocatively inviting a male gaze.
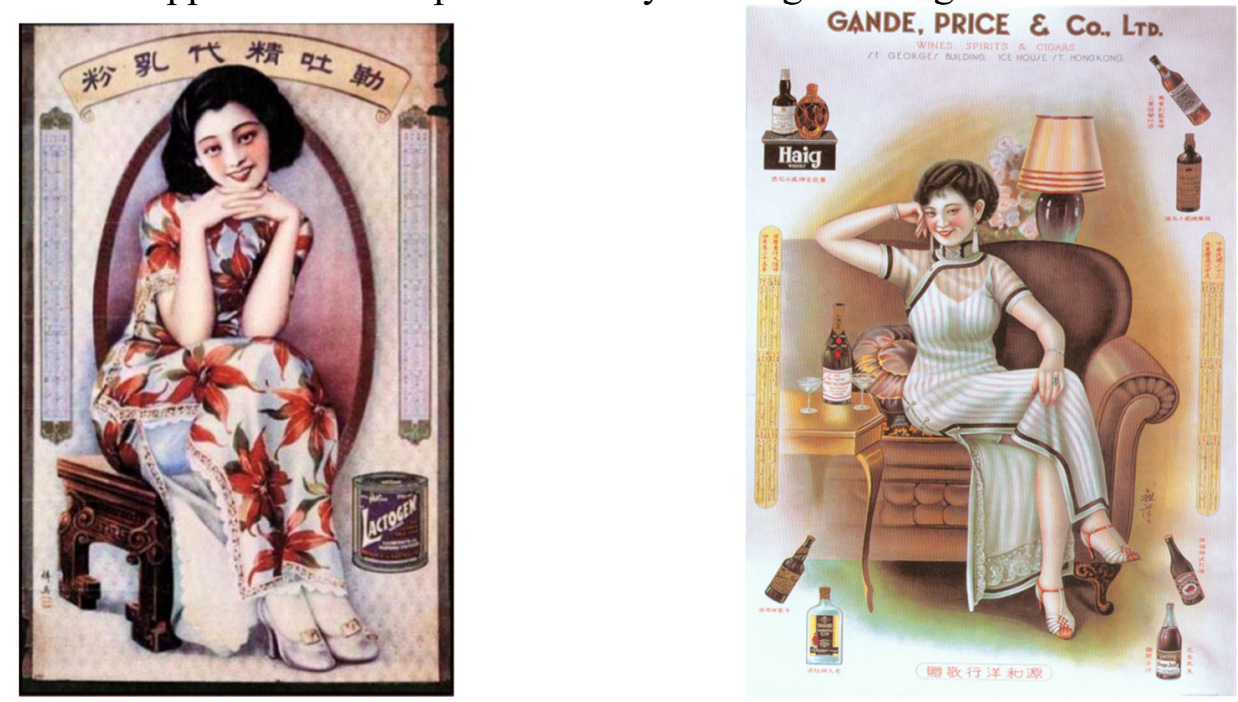

Figure 10. 1934 Calendar poster of Lactogen milk powder. Figure 11. Calendar poster of Yuanhe Trading Company.

\footnotetext{
${ }^{25}$ Laikwan Pang. "Advertising and the Visual Display of Women," in The Distorting Mirror: Visual Modernity in China.

${ }^{26}$ Ibid., 122.

${ }^{27}$ Ibid., 122.
} 


\section{Conclusion}

Deemed as a product of capitalist commodification of female body, the modern girl also represents a relatively autonomous consumerist icon. In the public discourse of imperial Japan and Republican China, nevertheless, she was constantly blamed for her decadent lifestyle and suspicious promiscuity connoted by her excessive pursuits of body aesthetics. Such polemic implies the inherent male domination in the modern gender discourse and the illusory nature of female subjectivity displayed in the public sphere.

More than a product of social gendering where a power imbalance exists, the modern girl image came into shape under a constant east-west cultural interplay. Given the inter-war Japan as an ambitious imperial power adopting wholesale westernization, Japanese modern girl style in cosmetic ads greatly drew on western aesthetic ideals by incorporating Caucasian female models and adopting a modernist design, with traditional Japanese fashion such as kimono gradually fading away. More intriguingly, cosmetic companies imposed a crafted Chinese identity on female models in their Manchurian advertising, selling a specifically Japanese imperial modernity towards their colonial subjects. By contrast, Chinese modern girl represented a hybrid style balancing between traditional aesthetics and western beauty ideals. In particular, foreign corporations utilized typically Chinese female models in cheongsam to dodge nationalist sentiments evoked by imported commodities. This visual emphasis on Chinese-ness sheds light on the inherent passiveness in Chinese modern experience, contrasting sharply with the spontaneous and aggressive Japanese imperial modernity behind Shiseido's beauty empire.

\section{References}

[1] Culver, Annika. A. "Shiseidō's 'Empire of Beauty': Marketing Japanese Modernity in Northeast Asia, 1932-1945", in Shashi: The Journal of Japanese Business and Company History 2, no.1 (2013): 6-22.

[2] Gordon, Andrew. "Japan in Wartime", in A Modern History of Japan: From Tokugawa Times to the Present. 3rd edition. New York: Oxford University Press, 2013.

[3] Pang, Laikwan. "Advertising and the Visual Display of Women," in The distorting mirror: visual modernity in China. Honolulu: University of Hawaii Press, 2007.

[4] Silverberg, Miriam. "The modern girl as militant," in Recreating Japanese Women: 1600-1945, edited By Gail Lee Bernstein. Berkeley: University of California, 1991.

[5] Stevens, Sarah E. "Figuring Modernity: The New Woman and the Modern Girl in Republican China." NWSA Journal 15, no. 3 (2003): 82-103.

[6] Weisenfeld, Gennifer. "Selling Shiseido I," in MIT Visualizing Cultures. Cambridge, MA: Massachusetts Institute of Technology, 2009. Assessed May 4, 2019. https://visualizingcultures.mit.edu/shiseido_01/index.html.

[7] Weisenfeld, Gennifer. "Ads \& Posters:1875-1941," in "Selling Shiseido, III: Image Galleries," in MIT Visualizing Cultures. Cambridge, MA: Massachusetts Institute of Technology, 2009. Assessed May 4, 2019. https://visualizingcultures.mit.edu/shiseido_03/index.html.

[8] Weinbaum, Alys Eve, et al., eds. "The Modern Girl Around the World" and "Who is afraid of the Chinese modern girl?" in The Modern Girl around the World: Consumption, Modernity, and Globalization. Durham, N.C.: Duke University Press, 2008. 